\title{
Vodarski pogled na uvajanje modro-zelene infrastrukture v mestih
}

Modro-zelena infrastruktura (MZI) so naravni in polnaravni (zato zelena) decentralizirani sistemi, namenjeni upravljanju padavinskih voda (zato modra) v mestih, ki hkrati opravljajo zelo raznovrstne ekosistemske storitve. Razen v nekaj tujih mestih, kjer so že sprejeli strategije za njihovo sistematično uvedbo, je uvajanje MZI omejeno na zgolj posamezne osamljene primere. To še posebej velja za Slovenijo, kjer uporaba MZI še ni postala pravilo. Zaradi utečenih prostorskonačrtovalskih praks imamo v slovenskih mestih zadosten delež razmeroma enakomerno razporejenih zelenih površin, ki pa niso načrtovane po načelih MZI, zato njihova večfunkcionalnost $\mathrm{z}$ vidika voda ni izkoriščena. Ker upravljanje mestnega prostora in pripadajočih prvin spada pod okrilje več strok, nas je zanimala predvsem povezava med prostorskim načrtovanjem in upravljanjem voda $\mathrm{v}$ mednarodnih strateških dokumentih in v slovenski zakonodaji. Na podlagi pregle- dane literature smo lahko sklenili, da je tovrstna povezava predvsem na mednarodni ravni, na nacionalni ravni pa je že šibkejša in je delovanje predvsem na izvedbeni ravni vezano na posamezne sektorje. V nadaljevanju so predstavljeni štirje primeri sistemskega uvajanja MZI v tujini: $\mathrm{v}$ Rotterdamu, Københavnu, v izbranih kitajskih mestih in v Filadelfiji, tem je skupno povezovanje med prostorskim načrtovanjem in upravljanjem voda pri načrtovanju MZI. Rezultati analize stanja so bili izhodišče za oblikovanje priporočil, $s$ katerimi je mogoče preseči sektorsko upravljanje mestnega prostora in doseči celovitejše upravljanje voda $\mathrm{v}$ (slovenskih) mestih.

Ključne besede: vodarstvo, prostorsko načrtovanje, urbana odvodnja, modro-zelena infrastruktura, podnebne spremembe 


\section{Uvod}

Učinki podnebnih sprememb in zdajšnje stanje v urbanih naseljih oblikujejo razmere, ki jim mestna infrastruktura $\mathrm{v}$ kritičnih trenutkih (npr. ekstremne padavine, vročinski valovi) vedno pogosteje ni več kos (Krajnc, 2019). Tudi za Slovenijo se po projekcijah podnebnih sprememb napoveduje, da lahko do sredine stoletja pričakujemo večje število ekstremnih vremenskih dogodkov: hudo vročino poleti, večjo spremenljivost temperature in padavin poleti, več močnih padavinskih dogodkov, okrepitev hidrološkega cikla, pogostejše zdajšnje stoletne poplave, precejšnje povečanje pogostosti poletne suše, verjetno povečanje števila dni z ugodnimi razmerami za nastanek poletnih neurij (Dolinar idr., 2014). Prilagajanje mest na ekstremne dogodke ali njihova krepitev odpornosti proti tem dogodkom je kompleksen proces, za katerega sta potrebna vključitev in sodelovanje vseh deležnikov, ki (so)oblikujejo in upravljajo mestni prostor (Klemen idr., 2020). V praksi deležniki pogosto delujejo samostojno in nepovezano, kar se vse bolj kaže kot ena izmed največjih ovir v upravljanju vode v mestih (Globevnik in Simoneti, 2020). Pri tem še posebej izstopajo vsebine, ki se šele uvajajo in (v Sloveniji) še nimajo ustaljenih načrtovalskih in upravljavskih pristopov, kot je na primer modro-zelena infrastruktura (v nadaljevanju: MZI) (Ravnikar in Goličnik Marušić, 2019).

Ključno za reševanje izzivov, ki jih mestom prinašajo podnebne spremembe, je obvladovanje urbanega vodnega kroga, kar je poleg vodne infrastrukture neposredno povezano tudi z (ne)utrjenimi mestnimi površinami in njihovim zaledjem. Zato ima pri prostorskem načrtovanju upravljanje voda vse večji pomen (Serrao-Neumann idr., 2017). Cilj je čim boljšse posnemanje naravnega površinskega odtoka, ki je bil značilen za območje pred posegom v prostor. Nove ureditve pa z utrjevanjem površin v mestu zahtevajo širjenje tako imenovane sive infrastrukture, kot imenujemo gospodarsko javno infrastrukturo. Padavinskih voda v upravljanju in urejanju mest ne smemo obravnavati le kot odpadek, ki ga je treba čim hitreje odvesti v kanalizacijski sistem. Takšno ravnanje namreč dodatno obremenjuje okolje in spodbuja linearno, namesto krožnega in trajnostno naravnanega upravljanja vodnih virov v mestu. Pri tem se izkaže, da je za upravljanje (vodnih) virov kritična povezava med urbanističnim načrtovanjem in trajnostnim razvojem (Agudelo-Vera idr., 2011).

S člankom želimo opozoriti na problematiko upravljanja voda $\mathrm{v}$ mestih, ki je lahko uspešno le $\mathrm{v}$ interdisciplinarnem povezovanju pristojnih iz vseh strok (vodarji, prostorski načrtovalci, urbanisti, arhitekti in krajinski arhitekti, gradbeniki, geografi, sociologi idr.), ki sodelujejo pri načrtovanju MZI in gospodarske javne infrastrukture, ter v medsektorskem povezovanju na ravni upravljanja mest. $\mathrm{V}$ nadaljevanju je najprej predstavljeno trenutno stanje upravljanja voda $\mathrm{v}$ mestih in posledice, ki jih prinašajo podnebne spremembe. Prikazani so tudi tuji primeri dobrih praks in priložnosti za izboljšanje upravljanja voda $\mathrm{v}$ mestih, ki jih omogoča MZI. Cilj prispevka je opozoriti tudi na nujno povezanost med prostorskim načrtovanjem in upravljanjem voda na strateški in izvedbeni ravni.

\section{Metodološki pristop}

V skladu z namenom in cilji prispevka smo izdelali primerjalno analizo dokumentov, na katerih temelji pristop upravljanja voda v slovenskih mestih. Zajeli smo tako mednarodno kot nacionalno raven $s$ področja urejanja prostora in upravljanja voda. V nadaljevanju smo proučili izbrane primere tujih praks, ki prikazujejo, kako lahko z ustreznim načrtovanjem in umeščanjem MZI v prostor rešujemo probleme (npr. poplave, onesnaževanje vodnih teles, urbani vročinski otoki) in hkrati ustvarjamo možnosti za dodatne ekosistemske storitve, npr. krepitev biotske raznovrstnosti, zmanjševanje onesnaženja, blaženje pojava vročinskih otokov. Ugotovitve obeh analiz smo nato medsebojno primerjali, predstavili rezultate in podali priporočila za celovitejše, medsektorsko usklajeno upravljanje voda v slovenskih mestih.

\section{Urbani vodni krog in modro-zelena infrastruktura}

\subsection{Razvoj urbanega vodnega kroga}

Širjenje mest in urbanizacija povečujeta delež neprepustnih površin, to $\mathrm{v}$ kombinaciji $s$ tradicionalnim načinom urbane odvodnje (tj. z uporabo sive infrastrukture) (Bacchin idr., 2014) povzroči spremembe $\mathrm{v}$ naravnem hidrološkem krogu. Te spremembe se kažejo $\mathrm{v}$ manjši infiltraciji in evapotranspiraciji ter povečanem površinskem odtoku (Butler idr., 2018). Iz tega izhaja neposredna povezava med zgodovino razvoja mestnega prostora in lokalnega vodnega kroga, pri čemer so se sčasoma spreminjali tudi koncepti upravljanja voda v mestih. Ti so sledili pričakovanjem družbe in razvoju novih pristopov in tehnologij, s katerimi so različne stroke reševale nastajajoče družbene težave (npr. bolezni, kot sta kolera in tifus, pomanjkanje pitne vode, poplave). Novi koncepti in strokovne rešitve so se med njihovim izvajanjem tako močno uveljavili, da so prešli tudi $\mathrm{v}$ zakonodajni okvir. Razvoj klasične zdravstvene hidrotehnike, ki se ukvarja z upravljanjem voda v mestih, za varovanje človekovega zdravja, je od antike do preloma tega tisočletja povzel Panjan (2005). Zanjo so značilne predvsem tri vodarske storitve: vodooskrba, odvajanje odpadnih voda in zašcita mest pred poplavami. Z rastjo družbenoekonomskega življenjskega standarda ter krepitvijo okoljske ozaveščenosti in pretečih podnebnih sprememb se v družbi krepi zavedanje, 
Preglednica 1: Razvoj pristopov upravljanja voda v mestih

\begin{tabular}{llll}
\hline Faza & Pristop upravljanja & Družbenopolitični vzroki/okoliččine & Vodarska storitev \\
\hline 1 & Vodooskrbno mesto & Oskrba s pitno vodo & Vodooskrbni sistemi \\
\hline 3 & Kanalizacijsko mesto & Zaščita javnega zdravja & Kanalizacijski sistemi \\
\hline 4 & Drenirano mesto & Zaščita pred poplavami & Odvodnja, kanaliziranje \\
\hline 5 & Mesto vodnih teles & Zaščita okolja, družbene vrednosti & Upravljanje točkovnih in razpršenih virov onesnaženja \\
\hline 6 & Vodno krožno mesto & Omejenost naravnih virov & $\begin{array}{l}\text { Raznovrstni, namenu ustrezni vodni viri in njihovo ohra- } \\
\text { njanje, spodbujanje zaščite vodnih teles }\end{array}$ \\
\hline
\end{tabular}

Vir: Brown idr. (2009)

da tovrstni linearni sistemi na okolje prenašajo eksternalije in dolgoročno niso vzdržni. Zato evropska direktiva o vodni politiki (Evropski parlament in Svet EU, 2000) in nacionalna zakonodaja z Zakonom o vodah (Ur. l. RS, št. 67/02) postavljata omejitve in regulatorni okvir za dosego dobrega ekološkega in kemijskega stanja vodnih teles. Sprejeti zakonodajni okvir kljub temu še vedno temelji na nadgradnji obstoječih linearnih sistemov (tj. izgradnja čistilnih naprav) in ne sledi sodobnim konceptom upravljanja voda, ki temeljijo na pristopih, značilnih za krožno gospodarstvo: zapiranje snovnih tokov, ponovna uporaba, obnova naravnih virov, uporaba virov različnih kakovosti glede na njihov namen itd. $Z$ vidika nastajajočih sprememb je Brown s sodelavci (2009) zgodovinski razvoj obstoječih in predlaganih konceptov upravljanja voda v mestih razdelil na šest faz, v okviru katerih je ciljno stanje vodno občutljivo mesto (Preglednica 1). Na splošno je večina slovenskih in evropskih mest $\mathrm{v}$ četrti fazi (t. i. mesto vodnih teles), z vključenimi prejšnjimi pristopi, ki zagotavljajo vodooskrbo, odvajanje odpadnih voda in zašcito pred poplavami, ter delnim izpolnjevanjem vodarskih storitev, ki so značilne za peto in šesto fazo.

Četrta faza, imenovana mesto vodnih teles, obravnava predvsem kakovost vodnih teles $v$ mestih in njihovo vključevanje $\mathrm{v}$ del urbanega življenja, saj prinašajo mnoge koristi (npr. možnosti za rekreacijo in preživljanje prostega časa, povečujejo vrednost okoliških nepremičnin, tvorijo zeleni sistem mesta), ki prispevajo tudi k izboljšanju javnega zdravja. Čeprav se je v zadnjih desetletjih močno izboljšalo stanje kakovosti voda, predvsem zaradi zapiranja industrijske proizvodnje ter izgradnje industrijskih in komunalnih čistilnih naprav, grožnjo še vedno predstavljajo tako razpršeni kot točkovni viri onesnaženja. Tipični primeri točkovnega nekontroliranega vira so razbremenilniki mešanih kanalizacijskih sistemov. Razpršenih virov onesnaženja ne moremo obvladovati s centraliziranimi sistemi, zato je potrebna uvedba decentraliziranih pristopov in tehnologij, za kar pa je nujna tudi prilagoditev poslovnega modela upravljanja vode $\mathrm{v}$ mestih, skupaj $s$ financiranjem in prenosom odgovornosti.
Peta faza, vodno krožno mesto, izhaja iz zavedanja, da so vodni viri količinsko in kakovostno omejeni. Zato prepoznava uporabo tudi drugih manj kakovostnih ali alternativnih vodnih virov (npr. padavinske vode, odpadne padavinske in komunalne odpadne vode) za zadovoljitev potreb, za katere voda ni potrebna. Ker je voda medij za prenos hranil, mineralov in energije, ta faza obravnava tudi njihovo pridobivanje ali obnovo iz odpadne vode, ki tako postane nov vir. Ta pristop zahteva tudi vključevanje drugih sektorjev (npr. kmetijstvo, prehrana, energetika) in prilagajanje njihove infrastrukture.

Šesta faza pomeni vodno občutljivo mesto, katerega razvoj spodbujajo podnebne spremembe in želja, da bi bila mesta čim bolj odporna proti tem spremembam, ter medgeneracijski prenos vrednosti, ki jo ima voda (tj. količinsko in kakovostno ohranjaje vodnih virov za prihodnje rodove). Čeprav je to vrsta upravljanja, predstavlja predvsem vizijo razvoja skupnosti in njenega trajnostnega odnosa do okolja in prostora. Zanjo je značilno, da so uporabljene tehnologije, infrastruktura in raba prostora $\mathrm{v}$ mestih raznovrstne in prilagodljive ter načrtovane na način, da krepijo trajnostne prakse in družbeni kapital. Pri tem ima pomembno vlogo povezava med družbo in tehnologijami. V takih okolišcinah bi se razmerje med vodarsko stroko in družbo (t. i. družbena pogodba) stalno spreminjalo in bi bil zanj potreben prilagodljiv institucionalen okvir.

$\mathrm{Z}$ vsako nadaljnjo fazo se upravljanje voda v mestih navezuje na čedalje več vključenih sektorjev, saj so vsi naravi elementi (voda, prst, zrak, živa bitja) med seboj povezani. To je na načelni ravni jasno in znano, vendar smo s pretirano segmentacijo upravljanja naravnih virov na podsisteme, ki izhajajo iz posameznih strok, izgubili holistični pristop $\mathrm{k}$ upravljanju. Za uveljavljanje novih celovitih konceptov upravljanja voda sta zato nujna povezovanje in sodelovanje z drugimi strokami, ki delujejo v mestnem prostoru. Tovrstno povezovanje se ponekod že uveljavlja z novimi pristopi k načrtovanju urbanega razvoja (Hung idr., 2012), ki ne iščejo več le tehnoloških rešitev, temveč se čedalje bolj približujejo zapiranju zanke v urbanem vodnem krogu tudi z uporabo MZI (Bacchin idr., 2014). Zelena infrastruktura namreč povečuje vrednost odprtih javnih 
površin in njihovega prispevka $\mathrm{z}$ ekosistemskimi storitvami v mestih, modra infrastruktura pa upravlja padavinske vode. Obe skupaj v sodobnem urbanističnem načrtovanju predstavljata bistveno kompleksnejše koristi. Opredelitev MZI kot interdisciplinarnega pristopa $\mathrm{k}$ urejanju mest je zato ključno za njeno razumevanje in uvedbo $\mathrm{v}$ prostorskonačrtovalski praksi.

\subsection{Modro-zelena infrastruktura}

Modro-zeleno infrastrukturo lahko opredelimo kot naravne in polnaravne (zato zelena) decentralizirane sisteme, namenjene upravljanju padavinskih voda (zato modra) v mestih, ki hkrati opravljajo širok nabor ekosistemskih storitev (Liao idr., 2017; Lamond in Everett, 2019). Njihova osnovna filozofija je posnemanje naravnih hidroloških procesov (tj. zadrževanje, infiltracija, evapo(transpi)racija), katerih cilj je upravljanje padavinskih voda na mestu nastanka in preprečiti njeno mešanje $s$ komunalno odpadno vodo. Ti ukrepi v Sloveniji še nimajo enotnega izraza, vsi prevodi izrazov v nadaljevanju so zato le poskus uskladitve $s$ slovensko terminologijo, niso pa še uveljavljeni v strokovni literaturi niti praksi, v angleščini pa se uporablja kar nekaj sorodnih izrazov in konceptov, ki temeljijo pretežno na podobnih procesih in tehnologijah. Tako se v Združenem kraljestvu najpogosteje uporablja izraz Sustainable Urban Drainage Systems (SUDS, trajnostni sistemi urbane odvodnje) (Woods Ballard idr., 2015), v ZDA se uporabljajo izrazi Low impact development (LID, posegi/ gradnja z majhnim okoljskim vplivom), Best management practice (BMP, najboljša upravljavska praksa) in Stormwater control measures (ukrepi za obvladovanje padavinskih voda), v Avstraliji pa izraz Water sensitive urban design (WSUD, vodi prilagojeno urbanistično načrtovanje) (Fletcher idr., 2015). Med seboj se razlikujejo predvsem v obsegu obravnavanega območja, kot so posamezno zemljišce, ulica, soseska, mestna četrt, mesto in celo večji regionalni sistemi. V zadnjem času se je začel pogosto uporabljati tudi izraz Nature-based solutions (sonaravne ali na naravi temelječe rešitve), ki zajema raznovrstne tehnologije, ki temelijo na naravnih procesih ali jih posnemajo, so stroškovno učinkovite ter hkrati prinašajo okoljske, družbene in gospodarske koristi ter krepijo odpornost (Langergraber idr., 2020). Te rešitve prek sistemskih posegov, ki so lokalno prilagojeni in učinkoviti z vidika rabe virov, prinašajo mestom in pokrajinam več narave ter naravnih elementov in procesov (Evropska komisija, 2020). Poudariti želimo, da gre za koncepte, ki temeljijo predvsem na istih tehnologijah in imajo iste cilje, ker pa so se sočasno razvijali na različnih koncih sveta in izhajajo iz raznovrstnih strok, so poimenovani drugače. Iz predstavljenih opredelitev je razvidno, da je treba MZI razumeti precej širše kot zgolj enega izmed pristopov $\mathrm{k}$ upravljanju voda. Gre za pristop, ki prinaša izboljšave ne le na področju upravljanja voda, temveč tudi na številnih drugih področjih, kot so podnebne spremembe, kmetijstvo, gozdarstvo, urbanistično načrtovanje, varstvo narave, preprečevanje nesreč in celo na področju regionalnega razvoja. Gre torej za izrazito interdisciplinaren koncept, ki pa v slovenski praksi še ni polno zaživel. Elementi MZI v urbanem prostoru najpogosteje predstavljajo del zelenih površin in tako v prostorsko načrtovalskem kontekstu tvorijo del zelenega sistema naselja ali zelene infrastrukture, kot jo uvaja Strategija prostorskega razvoja Slovenije do 2050 (Ministrstvo za okolje in prostor, 2020a).

Tudi v drugih državah, razen v nekaj izjemah, kot sta Združeno kraljestvo in Nizozemska, dodatne koristi, ki jih nudi MZI, žal še niso bile ustrezno predstavljene nacionalnim in lokalnim oblastem, upravljavcem gospodarske javne infrastrukture, prostorskim načrtovalcem in javnosti. $V$ nasprotju s tradicionalnim pristopom, ki temelji na odvajanju in zadrževanju vode v kanalizacijskem sistemu, za tovrstne sisteme še niso uveljavljeni smernice in programska orodja, namenjeni odločevalcem. Posledično so dodatne koristi MZI lahko prezrte, saj so merila ocenjevanja različic več rešitev nejasna, poleg tega dolgoročno delovanje teh sistemov za deležnike pomeni negotovost ali tveganje. Čeprav nekatera modelska orodja že vključujejo module za modeliranje MZI z vidika hidravlike in kakovosti vode, področje dodatnih koristi, kot so dodana vrednost (angl. amenity), biotska raznovrstnost ter dolgoročni vidiki stroškov in koristi, v ta orodja ni vključeno zadovoljivo (Chow idr., 2014). Nekatera programska orodja, kot je $E^{2} S T O R M E D$ (Morales-Torres idr., 2016) pa omogočajo celovito vrednotenje posameznih ukrepov z vsemi koristmi, ki jih prinašajo, vendar uporabljajo preprostejše hidrološko-hidravlične modele, zato je za ustrezno obravnavo priporočena uporaba rezultatov iz kompleksnejših modelov (Radinja idr., 2019).

Na sliki 1 so navedeni elementi MZI glede na njihov osnovni namen: zmanjševanje površinskega odtoka, zmanjševanje konice pretoka ali izboljšanje kakovosti vode. Hkrati je navedeno, $s$ katerim postopkom (npr. zadrževanje, infiltracija, evapotranspiracija) in koliko ukrep dosega posamezen namen in katere ekosistemske storitve omogoča.

\section{Celostni pristop k upravljanju voda v mestih}

Pri uveljavljanju novih konceptov in praks so zelo pomembni mednarodni in nacionalni strateški dokumenti, ki usmerjajo razvoj nekega področja. Glede na namen in cilje prispevka nas je zanimalo predvsem, koliko sta področji prostorskega načrtovanja in vode $\mathrm{v}$ mestih povezani, saj je treba za izvedbo MZI predvideti zadostne površine mestnega prostora. Tovrstna povezava je na mednarodni ravni močno zastopana in spodbujena (preglednica 2), v slovenski zakonodaji pa jo lahko zasledimo zgolj delno (preglednica 3). Opazimo lahko, da Slo- 


\begin{tabular}{|c|c|c|c|c|c|c|c|c|c|c|c|c|c|c|c|}
\hline \multirow{3}{*}{\multicolumn{3}{|c|}{$\begin{array}{l}\text { 『 Primarna funkoja } \\
\text { r Sekundarna funkcija } \\
\text { \& Nalejučno } \\
\text { +- Dodatna korist }\end{array}$}} & \multirow{2}{*}{\multicolumn{7}{|c|}{ Zmanj|janje pourşinskega odtoka }} & \multirow{2}{*}{\multicolumn{2}{|c|}{$\begin{array}{l}\text { Zmanjsanje konice } \\
\text { pourbinskega odtoka }\end{array}$}} & \multicolumn{4}{|c|}{ labolişanje kakovost vode } \\
\hline & & & & & & & & & & & & \multicolumn{2}{|c|}{ Biolosko c̈scenje } & \multicolumn{2}{|c|}{ Mehansko äisčenje } \\
\hline & & & \multirow{2}{*}{$\frac{\begin{array}{c}\text { Detevni } \\
\text { vit }\end{array}}{\square}$} & \multirow{2}{*}{\begin{tabular}{|c|}
$\begin{array}{c}\text { Zbiranje } \\
\text { deievorice }\end{array}$ \\
$凹$
\end{tabular}} & \multirow{2}{*}{$\begin{array}{c}\begin{array}{c}\text { Prepuatrie } \\
\text { uufjene povrsine }\end{array} \\
\oslash\end{array}$} & \multirow{2}{*}{$\begin{array}{l}\text { Zelenia } \\
\text { streha } \\
\emptyset\end{array}$} & \multirow{2}{*}{$\frac{\text { Drevo }}{\varnothing}$} & \multirow{2}{*}{$\begin{array}{c}\begin{array}{c}\text { Bloretenzijska } \\
\text { enora }\end{array} \\
\varpi\end{array}$} & \multirow{2}{*}{$\frac{\text { Ponikovalnice }}{\square}$} & \multirow{2}{*}{$\begin{array}{c}\begin{array}{c}\text { zadrievalhia } \\
\text { kotanja }\end{array} \\
*\end{array}$} & \multirow{2}{*}{$\frac{\text { Ribnik }}{r}$} & Gropentia & Eatravilent & Pelbeni & Aitteripas: \\
\hline \multirow{9}{*}{ 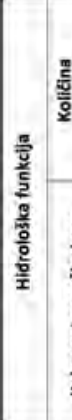 } & \multirow{4}{*}{ 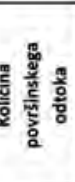 } & $\begin{array}{l}\text { Kratkotrajno } \\
\text { zadrievanje }\end{array}$ & & & & & & & & & & * & $*$ & $\checkmark$ & $\checkmark$ \\
\hline & & Infittrecija & $\nabla$ & $*$ & 田 & & r & 可 & $\square$ & $\%$ & $*$ & 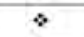 & $*$ & r & $\checkmark$ \\
\hline & & $\begin{array}{l}\text { Dolgotrajino } \\
\text { zadrievanje }\end{array}$ & $\checkmark$ & & & $\checkmark$ & $r$ & $\checkmark$ & $\%$ & $\square$ & $\checkmark$ & $\%$ & $\checkmark$ & . & $\checkmark$ \\
\hline & & Evapotranspiracija & $\checkmark$ & $*$ & & 可 & 甲 & 甲 & & $\checkmark$ & $*$ & 甲 & 曰 & $\%$ & $\checkmark$ \\
\hline & \multirow{5}{*}{ 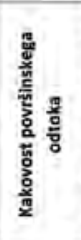 } & Sedimentacija & 甲 & $\%$ & $\checkmark$ & & & 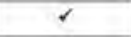 & & ఐ & 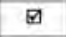 & 曰 & 甲 & 甲 & 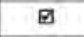 \\
\hline & & Filtracija & 口 & * & 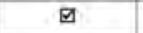 & 甲 & $*$ & $\checkmark$ & & $*$ & & 車 & $r$ & 可 & 甲 \\
\hline & & Precejanje & $\checkmark$ & $*$ & & & & $\checkmark$ & & $\%$ & & $\square$ & 甲 & & छ \\
\hline & & $\begin{array}{l}\text { Nadal|pja obdelava } \\
\text { (Kemicnas) }\end{array}$ & $r$ & & & $*$ & & & & $*$ & $*$ & $\theta$ & $\checkmark$ & 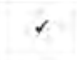 & \\
\hline & & $\begin{array}{l}\text { Nadaljnja obdelava } \\
\text { (bioloska) }\end{array}$ & 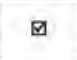 & & & $\theta$ & ø & $\checkmark$ & & $\&$ & $\$$ & 甲 & 曰 & 曰 & $\$$ \\
\hline \multirow{6}{*}{\multicolumn{2}{|c|}{ 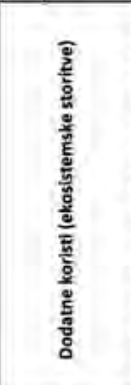 }} & $\begin{array}{l}\text { Žvijenjisho okolje } \\
\text { za Żivall }\end{array}$ & & + & & & + & + & & + & + & + & + & & \\
\hline & & Prijeten videz & & + & + & + & + & + & & + & + & + & + & & \\
\hline & & $\begin{array}{l}\text { Ponovna uporaba } \\
\text { powrsinskega } \\
\text { odtoka }\end{array}$ & & & & & & & & & + & & & & \\
\hline & & $\begin{array}{l}\text { Zagotavljanje } \\
\text { dodatnih } \\
\text { prepustnih povrsin }\end{array}$ & & & + & + & + & + & + & + & & & & & \\
\hline & & $\begin{array}{l}\text { Izbol|jojue kakovost } \\
\text { zraka }\end{array}$ & & + & + & + & + & + & & + & & + & + & & \\
\hline & & $\begin{array}{l}\text { Omogota } \\
\text { irobrazevanje }\end{array}$ & & + & + & + & & + & + & & & + & & & \\
\hline
\end{tabular}

Slika 1: Elementi modro-zelene infrastrukture ter njene funkcije in koristi (povzeto po Collett idr., 2013)

venija v nacionalno zakonodajo še ni v celoti prenesla priporočil iz mednarodnih dokumentov, zato je ta povezava šibkejša, saj sta zastopana le ponikanje padavinskih voda in načrtovanje zelenih površin (preglednica 3). V Sloveniji tudi (še) ni veljavnih standardov in uveljavljene prakse za načrtovanje MZI niti za urejeno ponikanje padavinskih voda (Radinja idr., 2017).

MZI je način, kako uskladiti posege v prostor (potrebe in razvoj) in doseči nekatere cilje urejanja prostora, ki jih določa Zakon o urejanju prostora (Ur. l. RS, št. 61/2017):

- $\mathrm{z}$ večfunkcionalnostjo MZI varuje prostor kot omejeno naravno dobrino, saj zagotavlja racionalnejšo rabo prostora,

- omogoča kakovostne življenjske razmere in zdravo življenjsko okolje, saj povečuje biotsko raznovrstnost,

- prispeva h krepitvi in varovanju zdravja ljudi, saj izboljšuje kakovost zraka in znižuje raven hrupa,

- varuje okolje, saj zmanjǔuje onesnaževanje (npr. razbremenilniki),

- prispeva k prilagajanju na podnebne spremembe,

- ustvarja razmere za zmanjševanje in preprečevanje naravnih in drugih nesreč, saj zmanjšuje verjetnost za poplave in hladi okolico.

Prostorsko načrtovanje in urbanizem imata v Sloveniji že dolgo tradicijo načrtovanja zelenih sistemov (npr. Zeleni sistem
Ljubljane; Kučan, 1994), kar se kaže tako v prostorskih dokumentih kot v prostoru. Na to kažejo tudi ureditve slovenskih mest in študije, ki so se ukvarjale s proučevanjem odprtega javnega prostora v slovenskih mestih (npr. Vertelj Nared, 2014; Volgemut, 2020). Kljub temu lahko ugotovimo, da prostorsko načrtovanje v Sloveniji obravnava področje upravljanja voda v mestih predvsem posredno, z zagotavljanjem zelenih površin ali sistemov (preglednica 3), kar pozitivno vpliva na urbano odvodnjo, saj sta zanje značilna manjši in upočasnjen površinski odtok glede na utrjene površine ter infiltracijska sposobnost. Vendar zelene površine (še) niso bile načrtovane $\mathrm{z}$ aktivno funkcijo zadrževanja in ponikovanja padavinskih voda (tj. ne prevzemajo tudi površinskega odtoka s sosednjih utrjenih površin), zato se to izvaja pasivno ali naključno (Ministrstvo za okolje in prostor, 2020b). Z vidika funkcionalnosti je zato treba zelene površine nadgraditi z elementi MZI, ki bodo zagotovili dodatne ekosistemske storitve, kot so odpornost prostora proti podnebnim spremembam, ohranjanje biotske raznovrstnosti, boljše delovanje ekosistemov in zagotavljanje drugih koristi za prebivalstvo in gospodarstvo, zlasti za javno zdravje in kakovost bivanja ter ohranjanje virov. Tako bodo zeleni sistemi naselij zagotovili razšsirjen nabor okoljskih in ekoloških funkcij ter tvorili zeleno infrastrukturo, kot jo uvaja predlog nove Strategije prostorskega razvoja Slovenije do 2050 (Ministrstvo za okolje in prostor, 2020a). Ta zeleno infrastrukturo na regionalni ravni opredeli kot zeleni sistemi regij, na lokalni 
Preglednica 2: Prostorsko načrtovanje in upravljanje voda v mestih na mednarodni ravni

\begin{tabular}{|c|c|}
\hline PROSTORSKO NAČRTOVANJE & VODA V MESTIH \\
\hline 1. Urbana agenda EU - Amsterdamski pakt (EK, 2016) & 1. Cilji trajnostnega razvoja ZN (OZN, 2015) \\
\hline $\begin{array}{l}\text { Prednostne teme med drugim zajemajo: prilagajanje na podneb- } \\
\text { ne spremembe (vključno z rešitvami zelene infrastrukture), traj- } \\
\text { nostno rabo prostora in sonaravne rešitve, kakovost zraka. }\end{array}$ & $\begin{array}{l}\text { - cilj 6: Vsem zagotoviti dostop do vode in sanitarne ureditve ter po- } \\
\text { skrbeti za trajnostno gospodarjenje z vodnimi viri; } \\
\text { - cilj 11: Poskrbeti za odprta, varna, vzdržljiva in trajnostna mesta in } \\
\text { naselja. }\end{array}$ \\
\hline 2. Nova urbana agenda (Ministrstvo za okolje in prostor, 2017) & 2. Načela za pametno ravnanje $z$ vodo v mestih (IWA, 2017) \\
\hline \multirow{5}{*}{$\begin{array}{l}\text { Zavezi za okoljsko trajnosten in prožen urbani razvoj, ki sta kar } \\
\text { najbolj povezani z vodo: } \\
\text { 72. Zavezujemo se izvajati dolgoročne postopke urbanističnega } \\
\text { in prostorskega načrtovanja ter prakse prostorskega razvoja, ki } \\
\text { vključujejo celostno načrtovanje in upravljanje vodnih virov, ob } \\
\text { upoštevanju mestno-podeželskih območij na lokalni in regionalni } \\
\text { ravni in ob sodelovanju pomembnih deležnikov in skupnosti. } \\
\text { 73. Zavezujemo se spodbujati varovanje in vzdržno rabo vode z } \\
\text { obnavljanjem vodnih virov na urbanih, primestnih in podeželskih } \\
\text { območjih, z zmanǰ̌evanjem količine odpadnih voda in njihovim } \\
\text { čiščenjem, zmanjševanjem vodnih izgub, spodbujanjem ponov- } \\
\text { ne rabe vode in povečevanjem zbiranja in zadrževanja vode ter } \\
\text { obnavljanja podzemne vode ob upoštevanju vodnega kroga. }\end{array}$} & $\begin{array}{l}\text { Načelo 2) Ustrezno urbanistično načrtovanje: } \\
\text { - načrtovanje in izvajanje prostorskih načrtov, ki omogočajo regenera- } \\
\text { tivne vodne storitve; }\end{array}$ \\
\hline & $\begin{array}{l}\text { - načrtovanje urbanih območij, ki zmanjšujejo poplavna tveganja. } \\
\text { Povečanje odpornosti mesta proti poplavnim tveganjem z načrto- } \\
\text { vanjem območij, ki bodo ob poplavi poplavljena, z uporabo trajno- } \\
\text { stnih sistemov urbane odvodnje; }\end{array}$ \\
\hline & - povečanje prijetnosti mest za življenje v njih z odprtimi vodnimi \\
\hline & $\begin{array}{l}\text { površinami. Od zelene infrastrukture ob cestah (deževni vrtovi, } \\
\text { ozelenjeni jarki) do modro-zelenih koridorjev s priložnostmi za rekre- } \\
\text { acijo, z vključujočimi javnimi prostori, ter za gospodarski razvoj, ki } \\
\text { ustvarjajo večnamenske prostore in infrastrukturo; }\end{array}$ \\
\hline & $\begin{array}{l}\text { - uvedba in uporaba takšnih gradbenih materialov (za strehe, fasade, } \\
\text { ceste in urbano pohištvo), ki preprečujejo oddajanje onesnažil, kadar } \\
\text { so izpostavljeni soncu ali dežju. }\end{array}$ \\
\hline
\end{tabular}

Preglednica 3: Prostorsko načrtovanje in upravljanje voda v mestih na nacionalni ravni

\begin{tabular}{ll}
\hline PROSTORSKO NAČRTOVANJE & VODA V MESTIH \\
\hline 1. Strategija prostorskega razvoja Slovenije (MOP, 2004) & 1. Strategija razvoja Slovenije 2030 (SVRK, 2017) \\
\hline
\end{tabular}

Na urbano odvodnjo se navezuje $v$ dveh točkah:

- pri razvoju mest in naselij: »... Z vidika varnosti naj bo v naseljih čim več zelenih površin zaradi izravnave velikih temperaturnih ekstremov ter omogočanja postopnega odvajanja padavinskih voda«;

- pri odvajanju in čiščenju odpadnih in padavinskih voda: padavinske in odpadne vode se odvajajo ločeno, kjer je to ekonomsko upravičeno in tehnično možno. Padavinske vode se čim dlje zadržijo na mestu, kamor so padle, zaledne vode pa se površinsko odvajajo mimo naselij do najbližjega površinskega odvodnika.

2. Strategija varstva in razvoja zelene infrastrukture v ljubljanski urbani regiji (RRA LUR, 2019)

Cilj 9: Trajnostno upravljanje naravnih virov bomo dosegli z:

a) uvajanjem ekosistemskega načina upravljanja naravnih virov in $s$ preseganjem sektorskega načina razmišljanja, med drugim s pravočasnim usklajevanjem nacionalnih in čezmejnih interesov na presečnih področjih voda - hrana - energija - ekosistemi, ki se bodo v prihodnosti spreminjali in prilagajali tudi zaradi posledic podnebnih sprememb; b) učinkovitim upravljanjem površinskih in podzemnih voda, obalnih in morskih virov ter $z$ doseganjem njihovega dobrega stanja.

Cilj 1: Izboljšano stanje okolja

Posebno skrb je treba nameniti upravljanju voda (ponikanje, zadrževanje vode, poplavna varnost) in načrtovanju rešitev, ki zadostijo več funkcijam hkrati (retencijske površine so hkrati privlačne za prostočasne dejavnosti in lahko ugodno vplivajo na mikroklimo).

Cilj 4: Blaženje podnebnih sprememb in prilagoditve nanje. Pomembna sta obvladovanje obeh ekstremov, povezanih z vodo (pomanjkanje vode in poplave), in povezanost $z$ drugimi dejavnostmi, na primer s kmetijstvom. Z urejanjem zelene infrastrukture oziroma s prostorskimi ukrepi v urbanih območjih je treba omiliti posledice tako ekstremnih padavin kot ekstremnih temperatur.

\section{Zakon o vodah (ZV-1, Ur. I. RS, št. 67/2002)}

Zakon predpisuje, da je varstvo pred škodljivim delovanjem padavinskih voda v ureditvenih območjih naselji naloga lokalne skupnosti, kar zajema zlasti ukrepe za zmanjševanje odtoka padavinskih voda z urbanih površin in ukrepe za omejevanje izlitja komunalnih in padavinskih voda. V odlokih lokalnih skupnosti je običajno predpisano ponikanje padavinskih voda, kjer je to mogoče in dopustno, če to ni mogoče, je treba čim bolj zmanjšati odtok padavinskih voda v javno kanalizacijo, z zadrževanjem ali njeno ponovno uporabo (Odlok o odvajanju in čiščenju komunalne in padavinske odpadne vode v Mestni občini Ljubljana, Ur. I. RS, št. 9/2018). 


\begin{tabular}{ll}
\hline PROSTORSKO NAČRTOVANJE & VODA V MESTIH \\
\hline 3. Zakon o urejanju prostora (ZUreP-2, Ur. I. RS, št. 61/2017) & $\begin{array}{l}\text { 3. Uredba o emisiji snovi in toplote pri odvajanju odpadnih voda v } \\
\text { vode in javno kanalizacijo (Ur. I. RS, št. 64/2012), Uredba o emisiji snovi } \\
\text { pri odvajanju padavinske vode z javnih cest (Ur. I. RS, št. 47/2005) }\end{array}$ \\
\hline
\end{tabular}

Zakon opredeljuje zelene sisteme kot načrtovani sistem varstva in razvoja zelenih površin na poselitvenih območjih ter drugih zelenih in ustvarjenih struktur v prostoru, ki se nanje navezujejo. Namen urejanja prostora (2. člen) je doseganje trajnostnega prostorskega razvoja s celovito obravnavo, usklajevanjem in upravljanjem njegovih družbenih, okoljskih in gospodarskih vidikov, tako da se kot cilj urejanja prostora med drugim prispeva k prilagajanju na podnebne spremembe ter se ustvarjajo razmere za zmanjševanje in preprečevanje naravnih ali drugih nesreč.

4. Uredba o prostorskem redu Slovenije (Ur. I. RS, št. 122/2004)

4. Uredba o metodologiji za oblikovanje cen storitev obveznih občinskih gospodarskih javnih služb varstva okolja (Ur. I. RS, št. 87/2012)

- Pri načrtovanju sistemov oskrbe z vodo se kot vir tehnološke vode, vode za gašenje ali druge vode, ki ni namenjena pitju, čim bolj uporabijo manj kakovostni vodni viri (52. člen).

- Padavinske vode s streh in teras objektov morajo prek ponikovalnih naprav, ponikovalnih jarkov ali ponikovalnega drenažnega cevovoda praviloma ponikati v okviru gradbene parcele, v skladu

Uredbi podrobneje določata, pod katerimi pogoji se padavinske odpadne vode (ne)smejo odvajati (ne)posredno v podzemne vode, neposredno v stoječe/tekoče celinske vode ali v morje. Omejitve so pogojene $z$ vrsto površine, s katere padavinske vode odtekajo, vodovarstvenimi pasovi ali vrsto vodonosnika, ki ga cesta prečka. s predpisi s področja varstva okolja.

pa kot zeleni sistem naselij, s čimer jo vsebinsko izenači z do zdaj uveljavljenim načrtovanjem zelenih sistemov.

Tudi slovenska zakonodaja na področju voda ne predpisuje uporabe elementov MZI, vendar te tudi ne prepoveduje, saj priporoča izvedbo ukrepov za zmanjšanje površinskega odtoka, zadrževanja ali ponikanje (preglednica 3). Zato jo lahko ob upoštevanju vseh značilnosti lokalnega prostora in področne zakonodaje začnemo uvajati že danes, kar potrjujejo tudi primeri uspešno izvedenih ukrepov MZI v Sloveniji (Ramšak in Oberžan, 2017; Klemen idr., 2020). Klemnova je s sodelavci (2020) ugotovila, da se ob pripravi prostorskih aktov praviloma ne izdelujejo strokovne podlage za ukrepe upravljanja padavinskih voda, kar vodi v nadaljnjo uporabo obstoječega koncepta upravljanja voda, z le redkimi izjemami uvajanja MZI v občinske prostorske načrte. K sistemskim ukrepom »sodelovanja med institucijami, krepitve strateskega načrtovanja, upoštevanja strokounih rešitev « poziva tudi Strategija varstva in razvoja zelene infrastrukture v Ljubljanski urbani regiji (RRA LUR, 2019), ki poudarja, da je celovito in vključujoče upravljanje prepoznano kot ključni dejavnik za ohranjanje koristi in za sprostitev potencialnih koristi zelene infrastrukture (Regionalna razvojna agencija LUR, 2019, str. 33). Hkrati omenjena strategija opominja, da je treba zeleno infrastrukturo načrtovati z zavedanjem, da gre za sistem, ki presega zgolj določanje namenske rabe $\mathrm{v}$ prostoru.
V Sloveniji so se nekatera mesta z uvajanjem MZI (npr. zelene strehe, obveznega zadrževanja/ponikanja padavinskih voda) že usmerila v uveljavitev ciljnega stanja: vodno občutljivo mesto, kot je predlagal Brown (2009). Manjka pa celovit sistemski pristop (tj. omenjeni fleksibilni institucionalni okvir), saj ni ustrezne povezave $z$ drugimi deležniki, ki (so)oblikujejo mestni prostor (arhitekti, urbanisti, prostorski načrtovalci). V nadaljevanju so predstavljeni nekateri primeri tujih mest, ki so take strategije/pristope upravljanja že sprejela in jih tudi izvajajo.

\section{Primeri dobrih praks}

Izbrali smo štiri primere sistemskega uvajanja MZI na mestni ali nacionalni ravni z Danske, Nizozemske, Kitajske in iz ZDA. $\mathrm{Z}$ njihovo geografsko zastopanostjo želimo poudariti, da gre pri uvajanju MZI, cilj česar je upravljanje urbanega vodnega kroga, za svetovni trend, ki nakazuje prihodnji razvoj na tem področju. Vsem primerom je skupno povezovanje med vodarskim in prostorsko načrtovalskim sektorjem, cilj pa je celovito načrtovanje MZI.

\subsection{København: prilagajanje na ekstremne padavinske dogodke}

Danski meteorološki inštitut opredeljuje padavinski dogodek kot ekstremen, kadar v 30 minutah pade več kot $15 \mathrm{~mm}$ padavin (Danish Meteorological Institute, 2019). Leta 2011 pa 
je v Københavnu padlo v 90 minutah $136 \mathrm{~mm}$ padavin, kar statistično pomeni dogodek, ki se zgodi zgolj enkrat v dva tisoč letih. Mesto je posledično utrpelo ogromno škode. Več kot 30 \% lastnikov objektov v mestu je vložilo zahtevke za zavarovalnino, skupna škoda pa je presegla 800 milijonov EUR (Arnbjerg-Nielsen idr., 2015). Kot odziv na ta in nekaj manj intenzivnih padavinskih dogodkov je mesto sprejelo načrt prilagajanja na podnebne spremembe Climate Adaptation Plan (The City of Copenhagen, 2011) in nato še načrt prilagajanja na nalive Cloudburst Management Plan (The City of Copenhagen, 2012), za izvajanje katerega bodo namenili približno pol milijarde evrov.

Slika 2 prikazuje šeststopenjski pristop za izbiro najustreznejše rešitve za obvladovanje nalivov:

- v prvem koraku je mestna uprava na podlagi podatkov in analiz trenutnega stanja opredelila in razvrstila območja v mestu, glede na to, kako jih nalivi ogrožajo;

- v drugem koraku so z uporabo hidrološko-hidravličnih modelov, ki so vključevali površinski odtok in kanalizacijski sistem, določili urbana porečja in njihovo poplavno ogroženost;

- v tretjem koraku so ovrednotili poplavne škode za trenutno stanje, skupaj s posrednimi stroški in vplivom podnebnih sprememb. Te znašajo med 55 in 80 milijoni EUR/leto od danes do leta 2110;

- v četrtem koraku so razvili katalog tipskih modro-zelenih elementov (tj. Cloudburst Toolkit) za obvladovanje nalivov (npr. zelena cesta, urbani potok, zadrževalni bulvar), ki so bili podlaga za razvoj ambicioznega načrta prilagajanja na prihodnje ekstremne nalive. Sledili so arhitekturno in krajinsko načrtovanje ter vizualizacija predlaganih rešitev in preverjanje njihove robustnosti;

- peti korak vključuje vse deležnike, ki nato sooblikujejo in s svojimi pogledi nadgradijo predlagane rešitve. Tako načrtovanje je iterativen proces, ki vodi k boljšim rešitvam in zagotavlja njihovo kakovost;

- v zadnjem koraku pa se predlagane alternativne rešitve finančno ovrednotijo in na podlagi analize stroškov in koristi se izbere najustreznejša rešitev.

\subsection{Rotterdam}

Rotterdam je največje evropsko pristanišče in je nastalo v delti rek Ren in Meuse, voda pa ga ogroža s štirih strani: morje, vodotoki, podtalnica in padavinske vode. Zaradi izjemne izpostavljenosti mesta in pretečih posledic podnebnih sprememb je mesto sprejelo strategijo prilagajanja na podnebne spremembe (Rotterdam Climate Initiative, 2013). Strategija temelji na konceptu, ki združuje premagovanje težav, povezanih z vodo, ter priložnosti za transformacijo urbanega prostora in družbenogospodarski razvoj. Temelj za načrtovanje ukrepov

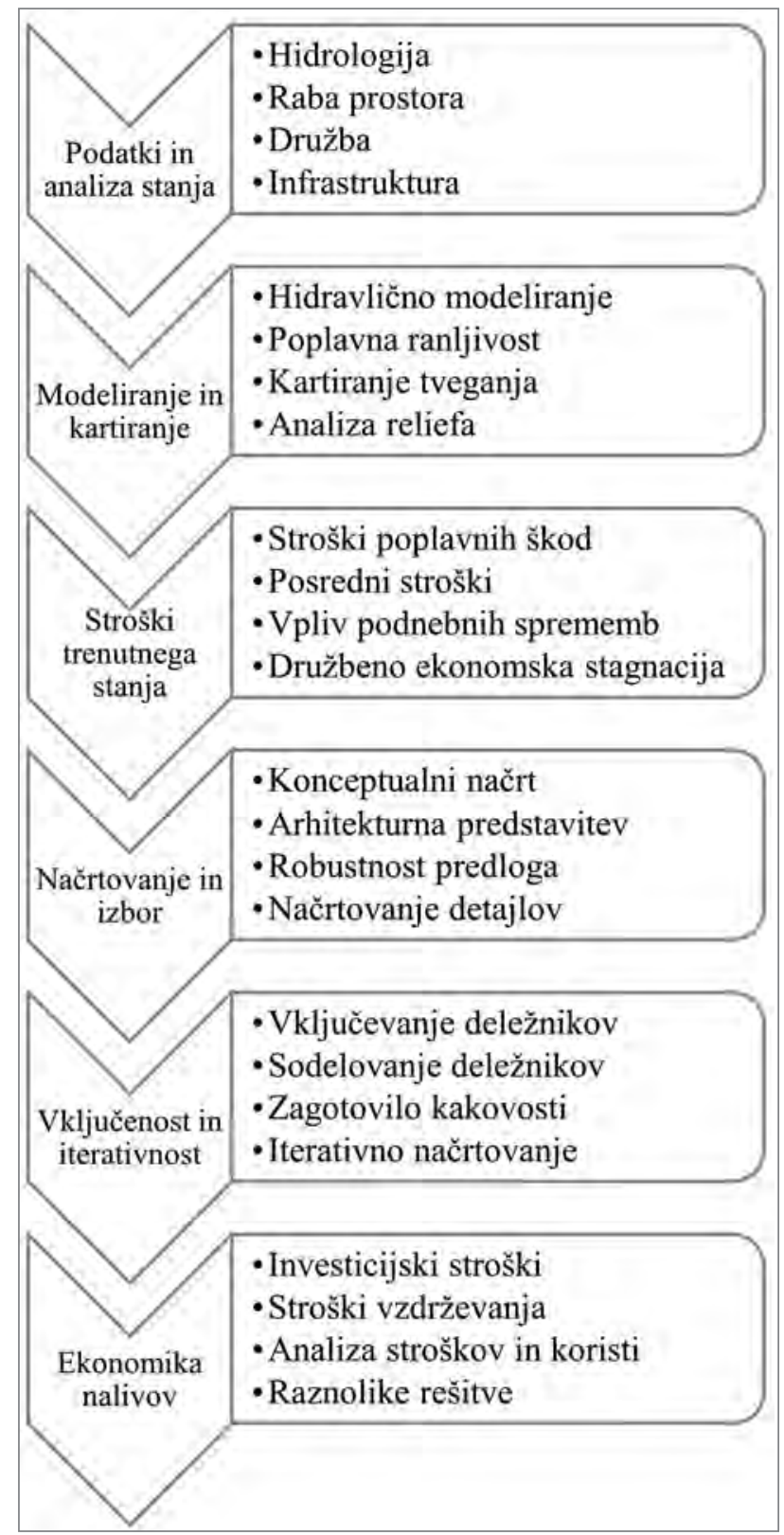

Slika 2: Københavnski pristop za obvladovanje nalivov (povzeto po Ramboll, 2016)

so rezultati hidrološko-hidravličnih modelov, s katerimi je določena poplavna ogroženost posameznih območij v mestu, in to zaradi morja, rek ali ekstremnih padavin. Pri spopadanju s temi je kot glavni ukrep predvidena MZI, ki mora padavinske vode zadržati na mestu, kjer padejo, in upočasniti njihov odtok. Posebna pozornost je pri načrtovanju "vodoodpornega" mesta namenjena individualni obravnavi posamezne lokacije, pri čemer pri načrtovanju ukrepov sodelujejo vodni odbori, urbanisti, mestna uprava in drugi deležniki. Ozaveščanje in aktivno vključevanje javnosti sta spodbujena $\mathrm{z}$ aktivnim in ciljno usmerjenim komuniciranjem. 


\subsection{Kitajska spužvasta mesta}

Kitajska vlada je zaradi težav v urbanem vodnem krogu (poplave in onesnaževanje vodnih teles), nastalih zaradi hitre urbanizacije kitajskih mest, razvila koncept t. i. spuzvvastih mest (angl. Sponge city). Vanj so leta 2014 vključili 30 mest po državi, vključno z megamesti, kot so Peking, Šanghaj, Tiandžin in Šendžen, ki so pilotna območja, iz katerih se bodo lahko dobre prakse in regulatorni okvir prenesli na druga mesta (Chan idr., 2018). Koncept spužvastih mest temelji na MZI in uveljavljanju šestih procesov pri upravljanju padavinskih voda v mestih: infiltraciji, upočasnitvi toka, zadrževanju, čiščenju, uporabi in odvajanju. Aktivnosti uvajanja koncepta v mesta se osredotočajo predvsem na ukrepe, ki so: 1) gradnja spužvastih stavb (npr. zelene strehe, deževni vrtovi), 2) gradnja spužvastih cest, pločnikov in trgov $\mathrm{z}$ uporabo prepustnih materialov, 3) gradnja spužvastih parkov in zelenih površin (npr. deževni vrtovi, poglobljeni travniki, grajena mokrišča), 4) zaščita in remediacija naravnih vodnih teles (npr. širitev mokrišč, vzdrževanja in ponovna uvedba naravnih rečnih tokov), 5) izboljšanje povezljivosti urbanih vodnih sistemov, ki omogoča njihovo neprekinjenost, 6) nadgradnja obstoječih sistemov odvodnje na način, da zagotavljajo zaščito pred poplavami in odvajanje presežnih količin vode, 7) gradnja ločenih sistemov za padavinske in komunalne odpadne vode (Liu idr., 2017). Dosedanji izsledki pri načrtovanju in delovanju MZI omogočajo prenos znanja iz pilotnih mest $v$ druga mesta, ki bodo lahko pristopila $\mathrm{k}$ hitrejšemu uvajanju MZI in boljšemu načrtovanju (Yin idr., 2021).

\subsection{Združene države Amerike: koncept MZI za obvladovanje odpadnih voda}

Razbremenilniki so elementi v mešanem kanalizacijskem sistemu, ki v času padavin presežne količine mešanice padavinskih in komunalnih odpadnih voda odvajajo neposredno v odvodnik ter tako ščitijo kanalizacijski sistem in posredno mesto pred poplavami. Hkrati so grožnja za okolje, saj čeprav je ta razredčena, še vedno odvajajo neočiščeno odpadno vodo v vodna telesa. Mesto Filadelfija se je na podlagi zahteve Ameriške okoljske agencije po vzpostavitvi dolgoročnega načrta za obvladovanje delovanja razbremenilnikov (United States Congress, 2002) odločilo za alternativni pristop. Namesto gradnje dodatne sive infrastrukture (npr. podzemni zadrževalniki, kolektorji) so se odločil za celovito uvajanje MZI. Nastal je 25-letni načrt z naslovom Zeleno mesto, čiste vode (Philadelphia Water Department, 2011). Izračunali so, da bo načrt po 45 letih mestu vrnil več koristi in dodane vrednosti, kot bo znašal vložek. Z načrtom so na podlagi strukturiranega informiranja in ozaveščanja vseh deležnikov dosegli, da meščani mestne ulice dojemajo drugače in sami vidijo priložnosti, kako se lahko do tedaj neprepustne površine spremenijo $\mathrm{v}$ vegetativno bujna območja, ki zadržujejo in čistijo padavinske odpadne vode ter jih nadzorovano odvajajo.

Uvedbi načrta je sledila priprava obsežnega priročnika z navodili, ki potencialnim investitorjem pred posegi v prostor omogoča preprosto seznanitev z vsemi potrebnimi zahtevami, ki jih mora projekt zagotoviti, da bo ustrezno obravnaval upravljanje voda na območju urejanja (Philadelphia Water Department, 2014). Mesto je na podlagi hidrološko-hidravličnih značilnosti razdeljeno na podobmočja, $s$ podanimi značilnostmi (npr. poplavna območja, tip kanalizacijskega sistema), na podlagi katerih lahko investitor ob uporabi priročnika določi splošne zahteve po upravljanju voda (npr. 100-odstotno ponikanje, delno zadrževanje in čiščenje padavinskih voda).

Kljub pozitivnemu napredku, ki ga je načrt prinesel, raziskovalci po nekem času ugotavljajo, da zasledovanje zgolj enega cilja ob uvajanju MZI ( $\mathrm{tj}$. zadrževanje velikih količin vode) lahko privede do sistemskega uvajanja omejenega nabora ukrepov MZI, ki omogočajo zgolj omejene koristi (Spahr idr., 2020). Zato so Spahr in sodelavci (2020) sklenili, da morajo mesta, če želijo doseči ekosistemske storitve, ki jih omogočajo rastline (tj. čiščenje zraka, zmanjševanje hrupa in učinka toplotnih otokov, prijeten videz, javno zdravje), bolj posegati po tovrstni MZI.

\subsection{Primerjava primerov dobrih praks}

Za oba proučevana evropska primera so bile glavni povod za spremembo paradigme $\mathrm{v}$ upravljanju urbanih voda preteče podnebne spremembe in napoved vedno pogostejših in intenzivnejših padavin, ki bodo povzročale poplave. Na drugi strani je bil povod za primera iz Kitajske in ZDA kakovost vodnih teles ali negativen vpliv urbanizacije nanje. Vsem primerom je skupno spoznanje, da siva infrastruktura ne more ponuditi rešitev za vse nastale in porajajoče se težave in da ne prinaša ekosistemskih koristi. Kot primerno rešitev so predstavljena mesta opredelila večfunkcionalno MZI, skladno s pristopom vodno občutljivih mest (preglednica 1), ki je bila ustrezno vključena v strateške dokumente, $\mathrm{v}$ katerih so opredeljeni tudi cilji (preglednica 4). Pomembno je, da so za sprejete strategije predvidena tudi javna sredstva, ki se usmerijo v doseganje zastavljenih ciljev. Menimo, da je uspešnost predstavljenih mest pri uvajanju MZI pogojena tudi z razvojem ustreznih smernic in načrtovalskih orodij, ki mestnim načrtovalcem omogočajo strokovno pomoč. Poleg tega jim je skupno tudi, da se v prostorsko načrtovanje vključuje upravljanje voda, pri čemer se z uporabo hidrološko-hidravličnih modelov: 1) opredelijo (trenutne in potencialne) kritične točke poplavne ogroženosti v urbanem prostoru ter se s simulacijami ovrednoti vpliv posa- 
Preglednica 4: Primerjava primerov dobrih praks iz tujine

\begin{tabular}{|c|c|c|c|c|}
\hline & København, Danska & Rotterdam, Nizozemska & 30 pilotnih kitajskih mest & Filadelfija, ZDA \\
\hline Povod & Poplave, podnebne spremembe & $\begin{array}{l}\text { Poplave, podnebne } \\
\text { spremembe }\end{array}$ & $\begin{array}{l}\text { Onesnaženost vodnega } \\
\text { okolja, poplave }\end{array}$ & $\begin{array}{l}\text { Onesnaženost vodnega oko- } \\
\text { lja - problem razbremenilnikov }\end{array}$ \\
\hline $\begin{array}{l}\text { Ime in leto } \\
\text { sprejetja pro- } \\
\text { grama }\end{array}$ & $\begin{array}{l}\text { Copenhagen Climate Adap- } \\
\text { tation Plan, 2011; Cloudburst } \\
\text { Management Plan, } 2012\end{array}$ & $\begin{array}{l}\text { Rotterdam Climate Change } \\
\text { Adaptation Strategy, } 2013\end{array}$ & $\begin{array}{l}\text { Sponge City Programme, } \\
2014\end{array}$ & Green City, Clean Waters, 2011 \\
\hline Cilj & $\begin{array}{l}\text { 1) Preprečiti odtok } z \text { več kot } 1 / 3 \\
\text { utrjenih površin v kanalizacijski } \\
\text { sistem } \\
\text { 2) Ob } 100 \text {-letnem nalivu največ } \\
10 \mathrm{~cm} \text { vode na površju (prepre- } \\
\text { čevanje poplav). }\end{array}$ & $\begin{array}{l}\text { Popolna odpornost mesta } \\
\text { proti podnebnim spre- } \\
\text { membam do leta } 2025 \text {. }\end{array}$ & $\begin{array}{l}\text { Do leta } 2030 \text { naj bi se na } \\
80 \% \text { urbanih območjih } \\
\text { najmanj } 70 \% \text { padavin } \\
\text { infiltriralo ali znova upo- } \\
\text { rabilo. }\end{array}$ & $\begin{array}{l}\text { V } 25 \text { letih preprečiti odtok z } \\
\text { več kot } 1 / 3 \text { utrjenih površin v } \\
\text { kanalizacijski sistem. }\end{array}$ \\
\hline $\begin{array}{l}\text { Razvite smerni- } \\
\text { ce in načrtoval- } \\
\text { ska orodja kot } \\
\text { odziv na zazna- } \\
\text { ne težave }\end{array}$ & $\begin{array}{l}\text { 1) Copenhagen Cloudburst } \\
\text { Formula (smernice za strateško } \\
\text { načrtovanje MZI), } \\
\text { 2) Copenhagen Cloudburst } \\
\text { Toolkit (katalog tipskih elemen- } \\
\text { tov MZI). }\end{array}$ & $\begin{array}{l}\text { 1) Interactive Climate } \\
\text { atlas (atlas prikazuje pred- } \\
\text { videne posledice podneb- } \\
\text { nih sprememb za posame- } \\
\text { zno lokacijo ob različnih } \\
\text { scenarijih), } \\
\text { 2) Climate adaptation } \\
\text { barometer (orodje za } \\
\text { oblikovanje strategije } \\
\text { prilagajanja na podnebne } \\
\text { spremembe in sledenje } \\
\text { njenemu izvajanju), } \\
\text { 3) Climate adaptation tool- } \\
\text { box (načrtovalsko orodje, } \\
\text { ki zajema potencialne } \\
\text { prilagoditvene ukrepe na } \\
\text { različnih ravneh urejanja } \\
\text { prostora). }\end{array}$ & $\begin{array}{l}\text { 1) Code of the Design } \\
\text { of Urban Green Spa- } \\
\text { ce (zakon, usklajen s } \\
\text { smernicami za spužvasta } \\
\text { mesta, s poudarkom } \\
\text { na usklajenem pristopu } \\
\text { za načrtovanje urbanih } \\
\text { zelenih površin), } \\
\text { 2) Code for Design of } \\
\text { Urban Road Enginee- } \\
\text { ring (zakon, usklajen s } \\
\text { smernicami za spužvasta } \\
\text { mesta, vsebuje poglavje } \\
\text { o MzI), } \\
\text { 3) Assessment Standard } \\
\text { for Sponge City Effec- } \\
\text { ts (tehnični standard } \\
\text { za vrednotenje učinkov } \\
\text { spužvastih mest). }\end{array}$ & $\begin{array}{l}\text { 1) Stormwater Management } \\
\text { Guidance Manual (smernice za } \\
\text { načrtovanje MZI, katalog tip- } \\
\text { skih elementov MZI), } \\
\text { 2) A Homeowner's Guide to } \\
\text { Stormwater Management (pri- } \\
\text { poročila gospodinjstvom za } \\
\text { upravljanje padavinskih voda). }\end{array}$ \\
\hline
\end{tabular}

meznih scenarijev MZI na urbani vodni krog, ter 2) ovrednoti vpliv MZI na kakovost urbanega površinskega odtoka in posledično ekološko stanje odvodnikov (vodnih teles).

\section{Sklepne ugotovitve}

$\mathrm{Z}$ upravljanjem mestnega prostora in pripadajočih prvin se ukvarja več strok. V članku smo predstavili trenutno stanje in izzive upravljanja voda v mestih v tujini in Sloveniji. Povezovanje med upravljanjem voda in prostorskim načrtovanjem je močno zastopano in spodbujeno v mednarodnih strateških dokumentih, v slovensko zakonodajo pa to povezovanje še ni $\mathrm{v}$ celoti preneseno. Zato je za slovenska mesta značilno sektorsko delovanje na področjih upravljanja voda in prostorskega načrtovanja.

Iz predstavljenih primerov dobrih praks upravljanja voda v mestih lahko sklenemo, da je ponekod sistemsko uvajanje MZI postalo že uveljavljen, ne več alternativen pristop urejanja mest. V Sloveniji tovrstnih primerov sistemskega uvajanja MZI še ne poznamo, obstaja pa zanje velik potencial, saj imamo v slovenskih mestih zadosten delež razmeroma enakomerno razporejenih zelenih površin (javnih in zasebnih), kar je posledica že utečenih prostorsko načrtovalskih praks (Ministrstvo za okolje in prostor, 2020b). Ker trenutno zelene površine niso načrtovanje po načelih MZI, njihova večfunkcionalnost, ki bi jo dosegli s prevzemanjem površinskega odtoka z okoliških utrjenih površin, ni (dovolj) izkoriščena. Tako ostaja v mestih velik potencial zelenih površin, ki bi lahko omogočale dodatne nad- ali podzemne retenzijske površine, s katerimi bi razbremenili kanalizacijski sistem in ohranili padavine $\mathrm{v}$ naravnem vodnem krogu. Predstavljeni primeri dobrih praks kažejo, da lahko prav izvedba mnogih decentraliziranih ukrepov močno izboljša vodno bilanco kanalizacijskega sistema ter zmanjša verjetnost preplavitve kanalizacijskega sistema in posledično mestnih površin.

Prikazani primeri dobrih praks kažejo, da sta pri načrtovanju MZI ključna interdisciplinarno sodelovanje več strok in medsektorsko usklajeno delovanje na načrtovalski in operativni ravni. $Z$ vidika upravljanja urbanega vodnega kroga pa je 
poglavitno, da se v prostorsko načrtovanje vključi tudi izdelava strokovnih podlag trajnostnega upravljanja vodnih virov in prilagajanja na podnebne spremembe. Za načrtovalsko in izvedbeno raven je izjemno pomembna izdelava smernic in tehničnih priročnikov za načrtovanje in dimenzioniranje MZI.

Sklenemo lahko, da kljub posameznim prizadevanjem v Sloveniji MZI še vedno ni prepoznana kot učinkovit koncept za celovito urejanje urbanega vodnega kroga. To zahteva njegovo celovito obravnavo, ki vključuje modeliranje, načrtovanje in dimenzioniranje najprimernejših ukrepov. Kljub temu prav ta prizadevanja kažejo na čedalje večje zavedanje o pomenu MZI in zahtevi po njenem sistematičnem vključevanju $\mathrm{v}$ zakonodajni okvir, ki bo zagotavljal ustrezno vključevanje ključnih deležnikov, interdisciplinarno sodelovanje strok in medresorsko usklajeno načrtovanje, pri čemer bi bil cilj teh prizadevanj celovito upravljanje voda v mestih.

\section{Matej Radinja}

Univerza v Ljubljani, Fakulteta za gradbeništvo in geodezijo, Oddelek za okoljsko gradbeništvo, Ljubljana, Slovenija

E-naslov: matej.radinja@fgg.uni-lj.si

Nataša Atanasova, Univerza v Ljubljani, Fakulteta za gradbeništvo in geodezijo, Oddelek za okoljsko gradbeništvo, Ljubljana, Slovenija E-naslov: natasa.atanasova@fgg.uni-lj.si

Alma Zavodnik Lamovšek, Univerza v Ljubljani, Fakulteta za gradbeništvo in geodezijo, Katedra za prostorsko planiranje, Ljubljana, Slovenija

E-naslov: alma.zavodnik@fgg.uni-lj.si

\section{Zahvala}

Zahvaljujemo se nosilcem projekta Zapiranje snovnih tokov z zelenimi tehnologijami (št. J2-8162) in raziskovalnega programa št. P2-0180, ki ju financira Javna agencija za raziskovalno dejavnost Republike Slovenije.

\section{Viri in literatura}

Agudelo-Vera, C. M., Mels, A. R., Keesman, K. J., in Rijnaarts, H. H. M. M. (2011): Resource management as a key factor for sustainable urban planning. Journal of Environmental Management, 92, str. 2295-2303. DOI: 10.1016/j.jenvman.2011.05.016

Arnbjerg-Nielsen, K., Leonardsen, L., in Madsen, H. (2015): Evaluating adaptation options for urban flooding based on new high-end emission scenario regional climate model simulations. Climate Research, 64, str. 73-84. DOI: 10.3354/cr01299

Bacchin, T. K., Ashley, R., Sijmons, D., Zevenbergen, C., in Van Timmeren, A. (2014): Green-blue multifunctional infrastructure: an urban landscape system design new approach. Conference proceedings: 13th Int. Conf. Urban Drainage, Saravak, Malezija. DOI: 10.13140/2.1.2061.5049

Brown, R. R., Keath, N., in Wong, T. H. F. (2009): Urban water management in cities: historical, current and future regimes. Water Science and Technology, 59, str. 847-855. DOI: 10.2166/wst.2009.029
Butler, D., Davies, J., James Digman, C., Makropoulos, C., in Davies, J. (2018): Urban drainage, 4. izdaja. CRC Press, Boca Raton, Florida. DOI: 10.1201/9781351174305

Chan, F. K. S., Griffiths, J. A., Higgitt, D., Xu, S., Zhu, F., Tang, Y. T., idr. (2018): "Sponge city" in China - A breakthrough of planning and flood risk management in the urban context. Land use policy, 76, str. 772-778. DOI: 10.1016/j.landusepol.2018.03.005

Chow, J. F., Savić, D., Fortune, D., Kapelan, Z., in Mebrate, N. (2014): Using a systematic, multi-criteria decision support framework to evaluate sustainable drainage designs. Procedia Engineering, 70, str. 343-352. DOI: 10.1016/j.proeng.2014.02.039

Collett, B., McCown, K., in Wall, S. (2013): Low impact development: opportunities for the PlanET region. Dostopno na: https://issuu.com/utkcoad/docs/2013_0807_-_lid_opportunities_for_t (sneto 19. 9. 2019).

Danish Meteorological Institute (2019): What to expect when DMI alerts clouds? Dostopno na: https://www.dmi.dk/nyheder/2019/hvad-skal-du-forvente-nar-dmi-varsler-skybrud/ (sneto 9. 6. 2019).

Dolinar, M., Vertačnik, G., Bertalanič, R., Dvoršek, D., Nadbath, M., Gartner, D., idr. (2014): Podnebne spremembe v Sloveniji - Podnebne podlage za pripravo ocene tveganj in priložnosti, ki jih podnebne spremembe prinašajo za Slovenijo 1. poročilo (različica 2). Ljubljana, Agencija RS za okolje.

Evropska komisija (2020): Nature-based solutions. Dostopno na: https:// ec.europa.eu/info/research-and-innovation/research-area/environment/ nature-based-solutions_sl (sneto 17. 7. 2020).

Evropski parlament in Svet EU (2000): Direktiva Evropskega parlamenta in Sveta 2000/60/ES z dne 23. oktobra 2000 o določitvi okvira za ukrepe Skupnosti na področju vodne politike, Uradni list Evropskih skupnosti, L 327, 22. 12. 2000, str. 1.

Fletcher, T. D., Shuster, W., Hunt, W. F., Ashley, R., Butler, D., Arthur, S., idr. (2015): SUDS, LID, BMPs, WSUD and more - The evolution and application of terminology surrounding urban drainage. Urban Water Jorunal, 12, str. 525-542. DOI: 10.1080/1573062X.2014.916314

Globevnik, L., in Simoneti, M. (2020): Obvladovanje vode v mestih naša skupna skrb. Slovenski vodar, 30, str. 11-14.

Hung, Y. Y., Aquino, G., in Waldheim, C. (2012): Landscape infrastructure: case studies by SWA. Birkhäuser, Basel. DOI: 10.1515/9783034611541

International Water Association (2017): Principles for water wise cities. Dostopno na: w https://iwa-network.org/wp-content/uploads/2016/10/ IWA_Brochure_Water_Wise_Communities_SCREEN-1.pdf (sneto 12. 3. 2019).

Klemen, K., Pergar, P., Futar, M., Bevc Šekoranja, B., in Konda, K. (2020): Problematika načrtovanja sonaravnih ukrepov za celovito upravljanje padavinskih voda na urbanih območjih. Gradbeni Vestnik, 69, str. 61-92.

Krajnc, U. (2019): Podnebne spremembe in poplavna ogroženost urbanih območij z lastnimi padavinskimi vodami. Gradbeni Vestnik, 68, str. 109-132.

Kučan, A. (1994): Zeleni sistem Ljubljane. Urbani izziv, 26/27, str. 65-72. DOI: 10.5379/urbani-izziv-1994-26-27-009

Lamond, J., in Everett, G. (2019): Sustainable blue-green infrastructure: A social practice approach to understanding community preferences and stewardship. Landscape and Urban Planning. 191, 103639. DOI: 10.1016/j.landurbplan.2019.103639

Langergraber, G., Pucher, B., Simperler, L., Kisser, J., Katsou, E., Buehler, D., idr. (2020): Implementing nature-based solutions for creating a resourceful circular city. Blue-Green Systems, 2, str. 173-185. DOI: 10.2166/bgs.2020.933 
Liao, K-H., Deng, S., in Tan, P. (2017): Blue-green infrastructure: New frontier for sustainable urban stormwater management. V: Tan P., Jim C. (ur.): Greening cities. Forms and Functions, str. 203-226. Singapur, Springer. DOI: 10.1007/978-981-10-4113-6_10

Liu, H., Jia, Y., in Niu, C. (2017): "Sponge city" concept helps solve China's urban water problems. Environmental Earth Sciences, 76, 473. DOI: $10.1007 /$ s12665-017-6652-3

Ministrstvo za okolje in prostor (2004): Strategija prostorskega razvoja Slovenije. Ljubljana.

Ministrstvo za okolje in prostor (2020a): Strategija prostorskega razvoja Slovenije 2050: Osnutek dokumenta v javni razpravi od 15. januarja 2020 do 15. marca 2020. Ljubljana. Dostopno na: https://www.gov.si/assets/ ministrstva/MOP/Dokumenti/Prostorski-razvoj/SPRS/SPRS-2050_gradivo-za-javno-razpravo.pdf (sneto 20. 1. 2020).

Ministrstvo za okolje in prostor (2020b): Zeleni sistem $v$ mestih in naseljih. Usmerjanje razvoja zelenih površin. Ljubljana. Dostopno na: https:// www.gov.si/assets/ministrstva/MOP/Dokumenti/Prostorski-red/zeleni-sistem.pdf (sneto 20. 1. 2021).

Morales-Torres, A., Escuder-Bueno, I., Andrés-Doménech, I., in Perales-Momparler, S. (2016): Decision support tool for energy-efficient, sustainable and integrated urban stormwater management. Environmetanl Modelling \& Software, 84, str. 518-528.

DOI: 10.1016/j.envsoft.2016.07.019

Odlok o odvajanju in čiščenju komunalne in padavinske odpadne vode v Mestni občini Ljubljana. Uradni list Republike Slovenije, št. 9/2018. Ljubljana.

Ministrstvo za okolje in prostor (2017): Nova urbana agenda. Ljubljana. Dostopno na: https://www.gov.si/assets/ministrstva/MOP/Publikacije/ bcd4138362/NUA.pdf (sneto: 9. 8. 2019).

Organizacija združenih narodov (2015): Spremenimo svet: Agenda za trajnostni razvoj do leta 2030. New York. Dostopno na: https://www.gov.si/ assets/ministrstva/MZZ/Dokumenti/multilaterala/razvojno-sodelovanje/ publikacije/Agenda_za_trajnostni_razvoj_2030.pdf (sneto 20. 1. 2021).

Panjan, J. (2005): Osnove zdravstveno hidrotehnične infrastrukture. Ljubljana, Univerza v Ljubljani, Fakulteta za gradbeništvo in geodezijo.

Philadelphia Water Department (2011): Green city, clean waters - implementation and adaptive management plan. Filadelfija, Pensilvanija, ZDA.

Philadelphia Water Department (2014): Stormwater management guidance manual. Philadelphia. Filadelfija, Pensilvanija, ZDA.

Radinja, M., Banovec, P., in Atanasova, N. (2017): Standardi na področju razpršenih ukrepov zadrževanja in ponikanja padavinskih voda na urbanih območjih. Ekolist, 14, str. 43-46.

Radinja, M., Comas, J., Corominas, L., in Atanasova, N. (2019): Assessing stormwater control measures using modelling and a multi-criteria approach. Journal of Environmental Management, 243, str. 257-268. DOI: 10.1016/j.jenvman.2019.04.102

Ramboll (2016): Copenhagen cloudburst plans. Dostopno na: https:// acwi.gov/climate_wkg/minutes/Copenhagen_Cloudburst_Ramboll_ April_20_2016\%20(4).pdf (sneto 9. 8. 2019).

Ramšak, V., in Oberžan, T. (2017): Problematika odvodnje padavinskih voda z urbaniziranih površin. V: Vuk, T. (ur.): Beton in ekstremne podnebne razmere. Ljubljana, Združenje za beton.

Ravnikar, Ž., in Goličnik Marušić, B. (2019): Na naravi temelječe rešitve: predstavitev projekta Connecting nature. Urbani izziv, 30(1), str. 72-74.

Regionalna razvojna agencija LUR (2019): Strategija varstva in razvoja zelene infrastrukture $v$ Ljubljanski urbani regiji. Ljubljana. Dostopno na: https://rralur.si/wp-content/uploads/2020/05/Strategija-ZILUR_2019.pdf (sneto 19. 1. 2021).
Rotterdam Climate Initiative (2013): Rotterdam. Climate change adaptation strategy. Dostopno na: http://www.urbanisten.nl/wp/wp-content/ uploads/UB_RAS_EN_Ir.pdf (sneto 20. 1. 2021).

Serrao-Neumann, S., Renouf, M., Kenway, S. J., in Low Choy, D. (2017): Connecting land-use and water planning: Prospects for an urban water metabolism approach. Cities, 60(A), str. 13-27.

DOI: 10.1016/j.cities.2016.07.003

Služba Vlade Republike Slovenije za razvoj in evropsko kohezijsko politiko (2017): Strategija razvoja Slovenije 2030. Ljubljana, SVRK.

Spahr, K. M., Bell, C. D., McCray, J. E., in Hogue, T. S. (2020): Greening up stormwater infrastructure: Measuring vegetation to establish context and promote cobenefits in a diverse set of US cities. Urban Forestry \& Urban Greening, 48, 126548. DOI: 10.1016/j.ufug.2019.126548

The City of Copenhagen (2011): Copenhagen climate adaptation plan. Dostopno na: https://en.klimatilpasning.dk/media/568851/copenhagen_adaption_plan.pdf (sneto: 12. 4. 2019).

The City of Copenhagen (2012): The city of Copenhagen. Cloudburst management plan 2012. Dostopno na: https://en.klimatilpasning. $\mathrm{dk} /$ media/665626/cph___cloudburst management_plan.pdf (sneto: 12. 4. 2019).

United States Congress (2002): Federal water pollution control act. Dostopno na: https://www.epa.gov/sites/production/files/2017-08/ documents/federal-water-pollution-control-act-508full.pdf (sneto: 12. 4. 2019).

Uredba o emisiji snovi in toplote pri odvajanju odpadnih voda v vode in javno kanalizacijo. Uradni list Republike Slovenije, št. 64/2012, 64/2014 in 98/2015. Ljubljana.

Uredba o emisiji snovi pri odvajanju padavinske vode $z$ javnih cest. Uradni list Republike Slovenije, št. 47/2005. Ljubljana.

Uredba o metodologiji za oblikovanje cen storitev obveznih občinskih gospodarskih javnih služb varstva okolja. Uradni list Republike Slovenije, št. 87/2012, 109/2012 in 76/2017. Ljubljana.

Uredba o prostorskem redu Slovenije. Uradni list Republike Slovenije, št. 122/2004, 33/2007. Ljubljana.

Vertelj Nared, P. (2014): Vloga javnega prostora kot podpora urbanemu razvoju na primeru majhnih mest v Sloveniji. Doktorska disertacija. Ljubljana, Univerza v Ljubljani, Fakulteta za gradbeništvo in geodezijo.

Volgemut, M. (2020): Vpliv lokacije storitev splošnega pomena na razvoj odprtega javnega prostora na primeru majhnih mest v Sloveniji. Doktorska disertacija. Ljubljana, Univerza v Ljubljani, Fakulteta za gradbeništvo in geodezijo.

Woods Ballard, B., Wilson, S., Udale-Clarke, H., Illman, S., Scott, T., Ashley, R., idr. (2015): The SUDS manual. London, Construction Industry Research and Information Association. Dostopno na: https://www. susdrain.org/resources/SuDS_Manual.html (sneto: 20. 1. 2021).

Zakon o urejanju prostora. Uradni list Republike Slovenije, št. 61/2017. Ljubljana.

Zakon o vodah. Uradni list Republike Slovenije, št. 67/02, 2/04 - ZZdrl-A, 41/04 - ZVO-1, 57/08, 57/12, 100/13, 40/14 in 56/15. Ljubljana.

Yin, D., Chen, Y., Jia, H., Wang, Q., Chen, Z., Xu, C., idr. (2021): Sponge city practice in China: A review of construction, assessment, operational and maintenance. Journal of Cleaner Production, 280(2921), 124963. DOI: $10.1016 /$ j.jclepro.2020.124963 